\title{
Hermeneutički kontinuitet između J. B. Metza i pape Franje
}

\author{
IVICA RAGUŽ ${ }^{*}$ - MIRKo VLK ${ }^{* *}$ \\ • https://doi.org/10.31823/d.29.3.2 • \\ UDK: 27-31-05 Metz, J.B. ${ }^{*} 272-732.2$ Franjo • Izvorni znanstveni rad \\ Primljeno: 1. srpnja 2021. • Prihvaćeno: 24. rujna 2021.
}

${ }^{*}$ Prof. dr. sc. Ivica

Raguž, Katolički bogoslovni fakultet u Đakovu, Sveučilište

J. J. Strossmayera u Osijeku,

Petra Preradovića 17, p. p. 54, 31400 Đakovo, Hrvatska, ivica.raguz@ os.t-com.hr

** Dr. sc. Mirko Vlk,

Hrvatska katolička misija Hamburg, Schmilinskystrasse 14, 20099 Hamburg, Njemačka, mirko.vlk. op@gmail.com

Sažetak: Članak razmatra usporedne teme izmedu nove političke teologije Johanna Baptista Metza i pastoralno-teološkoga pristupa pape Franje tražeći dublju poveznicu ponad zajedničkoga nasljeđa Drugoga vatikanskoga sabora. Kroz usporedbu postidealističke teološke paradigme nove političke teologije, kao i njezine zadaće da bude >teološkom hermeneutikom političke etike «, te Papinih pastoralnih načela iz apostolske pobudnice Evangelii gaudium, ukorijenjenih $u$ argentinskoj $\gg$ teologiji naroda ${ }$, ovaj članak ustanovljuje kako Metza $i$ Svetoga Oca veže naglasak na povijesnoj svijesti u teološkoj refleksiji, točnije, kako su izričaj pologa vjere i oblici življenja vjere uvjetovani društveno-povijesnim prilikama, zbog čega se spasenje ne može razmatrati zasebno od težnje za slobodom, mirom i pravdom. Iz toga proizišla Metzova teodicejski izražena osjetljivost na patnju i Papino isticanje Božjega milosrđa također se medusobno nadopunjuju.

Ključne riječi: nova politička teologija, Johann Baptist Metz, papa Franjo, milosrde, teološka hermeneutika političke etike, patnja.

\section{Uvod}

Kako se 2013. godine novoizabrani papa Franjo tijekom svoga prezbiterata i episkopata prije svega usmjerio na pastoralnu skrb za svoju biskupiju i administrativne dužnosti pri Rimskoj kuriji, njegove se teološke stavove isprva tek djelomično naziralo kroz javne istupe ili sporadične osvrte nekadašnjih suradnika. Detaljniji uvid u Papinu teologiju slijedio je tek u apostolskim pobudnicama Evangelii 
gaudium - Radost Evandelja, ${ }^{1}$ Amoris laetitia - Radost ljubavi, ${ }^{2}$ Gaudete et exsultate - Radujte se i kličite, ${ }^{3}$ Christus vivit - Krist živi i Querida Amazonia - Ljubljena Amazonija, ${ }^{5}$ papinskoj buli o najavi Izvanrednoga jubileja milosrda Misericordiae vultus - Lice milosrda ${ }^{6}$, kao i enciklikama Laudato si $^{7}$ i Fratelli tutti ${ }^{8}$.

Govoreći o važnim temama po život Crkve, kao i budućnost cijeloga svijeta, papa Franjo otkriva svoju teološku i pastoralnu perspektivu ukorijenjenu u dokumentima ${ }^{9}$ Drugoga vatikanskoga sabora koji su ključni po Crkvu u Latinskoj Americi, kao i specifičan $\gg$ obrazac mišljenja $\ll{ }^{10}$ koji saborski nauk tek nagoviješta. $\mathrm{Na}$ tom tragu među prvima je njemački teolog Johann Baptist Metz izgradio projekt nove političke teologije. Naime riječ je o postidealističkoj misaonoj paradigmi koja prihvaća uvjetovanost teološke refleksije, a time i izričaja vjere, društvenim uvjetima i povijesnima kretanjima, zbog čega je nužno i antropocentrična. Nova politička teologija stoga ne promatra povijest spasenja s obzirom na čovjekovu transcendentalnu svrhu niti odnos Boga i čovjeka razumijeva isključivo personalistički. Radije, u jednom posve praktičnom smislu pita kako sada i ovdje postati »subjekt pred Bogom «, odnosno kako održavati žar eshatološkoga iščekivanja bez privatiziranja vjere i posljedična pada u pasivnost koja niječe samu mesijansku srž kršćanstva.

${ }^{1}$ FRANJO, Evangelii gaudium - Radost Evandelja, Apostolska pobudnica o naviještanju evandelja u suvremenom svijetu, Zagreb, 2015. (= EG).

${ }^{2}$ FRANJO, Amoris laetitia - Radost ljubavi. Posinodska apostolska pobudnica o ljubavi u obitelji, Zagreb, 2017. (= AL).

${ }^{3}$ FRANJO, Gaudete et exsultate - Radujte se i klicite. Apostolska pobudnica o pozivu na svetost u suvremenom svijetu, Zagreb, 2019. (dalje: GE).

${ }^{4}$ FRANJO, Christus vivit - Krist živi. Posinodska apostolska pobudnica mladima i cijelome Božjem narodu, Zagreb, 2019. (= CV).

${ }^{5}$ FRANJO, Querida Amazonia - Ljubljena Amazonija, Posinodska apostolska pobudnica narodu Božjem i svim ljudima dobre volje, Zagreb, 2020. (= QA).

${ }^{6}$ FRANJO, Misericordiae vultus - Lice milosrda. Bula najave izvanrednoga jubileja milosrda, Zagreb, 2015. (= MV).

${ }^{7}$ FRANJO, Laudato si' - Enciklika o brizi za zajednički dom (24. V. 2015.), Zagreb, 2015. (= LS).

${ }^{8}$ FRANJO, Fratelli tutti - Enciklika o bratstvu i socijalnom prijateljstvu, Zagreb 2021. (=FT).

${ }^{9}$ DRUGI VATIKANSKI KONCIL, Lumen gentium. Dogmatska konstitucija o Crkvi (21. XI. 1964.), u: ISTI, Dokumenti, Zagreb, 2008. (= LG); DRUGI VATIKANSKI KONCIL, Ad gentes. Dekret o misijskoj djelatnosti Crkve (7. XII. 1965.), u: ISTI, Dokumenti (= AG); DRUGI VATIKANSKI KONCIL, Gaudium et spes. Pastoralna konstitucija o Crkvi u suvremenom svijetu (7. XII. 1965.), u: ISTI, Dokumenti (= GS).

${ }^{10}$ J. B. METZ, Politička teologija: 1967. - 1997., Zagreb, 2004., 312. 
Svjestan rizičnosti politizacije vjere i poslanja Crkve, Metz koncipira novu političku teologiju kao $\gg$ teološku hermeneutiku političke etike $\ll{ }^{11}$ čiji je zadatak biti kritički korektiv svih manjkavosti moderne društveno-političke prakse, kao i poticaj na što potpunije ostvarenje evanđeoskih vrijednosti. ${ }^{12}$ Postoji li između Metza i pape Franje nešto više od akcidentalne sličnosti zbog zajedničkoga nasljeđa Drugoga vatikanskoga sabora? Tražeći odgovor na to pitanje, ovaj će članak razlučiti srž Papina pastoralno-teološkoga pristupa i razmotriti teme njegovih enciklika i apostolskih pobudnica ne bi li pokazao kako papa Franjo govori o poslanju Crkve u svijetu upravo u kategorijama nove političke teologije.

\section{Nova politička teologija Johanna Baptista Metza}

Nova politička teologija njemačkoga katoličkoga teologa Johanna Baptista Metza, uvažavajući pritom utjecaj Karla Rahnera, Theodora W. Adorna, Ernsta Blocha i Waltera Benjamina, ponajviše predstavlja pozitivnu reakciju na Drugi vatikanski sabor i temeljitiju razradu nekih bitnih poticaja saborskoga nauka kao što su kritičko suočavanje s nasljeđem prosvjetiteljstva, uvažavanje kulturne policentričnosti Crkve, kao i složen odnos vjere i svijeta. ${ }^{13}$ Metz tako u šezdesetim godinama 20. stoljeća napušta dotadašnju idealističko-transcendentalističku paradigmu bavljenja teologijom i tijekom sljedećih pola stoljeća razvija i usavršava tzv. postidealistički teološki pristup, osjetljiv na društveno-povijesnu uvjetovanost vjere u svijetu koji naziva $\gg$ političkom $\ll$ teologijom.

U inicijalnoj fazi razrade nove političke teologije Metz pozitivno prosuđuje sekularizaciju kao pomak u percepciji svijeta od divinizirane prirode prema svojevrsnoj $\gg$ pozornici « na kojoj se odvija drama čovjekova pada i spasenja, čime se svijet otkriva i kao povijest. Nasuprot idealističkoj teološkoj paradigmi, koja utvrđuje smisao egzistencije čovjeka i svijeta iz transcendencije, Metz promatra čovjeka s obzirom na eshatološko usmjerenje povijesti spasenja ne razdvajajući ju od povijesti svijeta. Stoga odbacuje i pasivnost pri iščekivanju Kristova povratka, već potiče na uvijek veće očovječenje svijeta motivirano prodorom eshatona kao one konačne budućnosti. ${ }^{14}$

Zato bi teologija trebala biti osjetliva na društveno-povijesna kretanja, pa Metz artikulira ključne zadaće takve »političke « teologije. Prvo, deprivatizirati vjeru,

\footnotetext{
${ }^{11}$ Isto, 62.

${ }^{12}$ Usp. isto, 62-65.

${ }^{13}$ Usp. J. B. METZ, Memoria passionis: provokativni spomen u pluralističkom društvu, Zagreb, 2009., 264-267., 317-320.

${ }^{14}$ Usp. J. B. METZ, Theology of the World, New York, 1973., 16-25., 51-60., 81-92.
} 
jer čovjek kao subjekt društva i povijesti ostaje uvjetovan, ali ne i određen, društveno-povijesnim okolnostima. Drugo, redefinirati odnos vjere i svijeta kao odnos teorije i prakse radi kritičkoga suočavanja s nasljeđem prosvjetiteljstva, s onim elementima današnjega svjetonazora koji su u napetosti prema eshatonu. Ta kršćanska odgovornost za svijet nije individualna ni privatna, zato nova politička teologija vidi Crkvu kao »instituciju kritičke slobode vjere « nasuprot naizgled plauzibilnim predodžbama u javnom mnijenju, ali zapravo ideološkim narativima koji priječe uspješan navještaj evanđelja. ${ }^{15}$

Razrađujući dalje novu političku teologiju kao praktičnu fundamentalnu teologiju, Metz promišlja o besubjektnosti teologije te se sve više koncentrira na teodicejsko pitanje o razlogu patnje i zaborava žrtava povijesti. To ga dovodi do pitanja kako učiniti čovjeka »subjektom pred Bogom « koji preuzima odgovornost za svijet bez obzira na obespravljujuće i opresivne društveno-povijesne uvjete. U toj fazi svoga teološkoga rada Metz znatno utječe na latinoameričku teologiju oslobođenja, ali i sam preuzima neke njezine elemente, kritizirajući inertnost europske »buržujske religije « i ravnodušnost na tuđu patnju. Metz otada nedvojbeno razumije i promiče »političku « teologiju kao autentičnu kršćansku hermeneutiku društvenooslobađajuće političke prakse za univerzalnu subjektnost koristeći se kategorijama spomena, pripovijedanja i solidarnosti. ${ }^{16}$

Naime $\gg$ temeljni hermeneutički problem teologije $\ll{ }^{17}$, koji Drugi vatikanski sabor artikulira kao pitanje odnosa vjere i svijeta, Metz koncipira kao odnos teorije i prakse u kojem prednost drži upravo praksa vjere, odnosno »nasljedovanje Krista $\ll$ koje je fundamentalno operativno kristološko načelo teologije. Tako »primat prakse « za Metza postaje polazište teološke refleksije nad iskustvom Boga u povijesti i predstavlja odmak od ahistorijske koncepcije odnosa vječne Objave i nestalne povijesti kao nepomirljivoga razilaženja. Kroz taj novi odnos vjere i svijeta Metz također želi započeti kritičko-dijalektički dijalog s modernom. ${ }^{18}$

No kako učiniti praksu vjere kao »nasljedovanje Krista « razumljivu modernom dobu izgrađenom na idealu emancipacije? Metz to postiže načelom memoria passionis, koje razumije kao kristološki arhetip iskustva patnje i anticipaciju uskrsnuća koje je onaj mesijanski vid vjere i odgovor na »teodicejsko pitanje « o razlogu patnje koje ne može biti riješeno u povijesti. Zato nova politička teologija, čije je

\footnotetext{
${ }^{15}$ Usp. isto, 108-115., 149-155.

${ }^{16}$ Usp. J. B. METZ, Faith in History and Society: Toward a Practical Fundamental Theology, New York, 2015., 61-78., 208-214.

${ }^{17}$ J. B. METZ, Politička teologija: 1967. - 1997., 38.

${ }^{18}$ Usp. isto, 61-67.
} 
memoria passionis temeljno hermeneutičko načelo, upozorava na $\gg$ kulturnu amneziju «, kolektivni zaborav patnje marginaliziranih i žrtava povijesti, posebno katastrofa kao što je holokaust. Iz istoga razloga »teologija nakon Auschwitza « nije izolirana od društveno-povijesnih okolnosti i posljedica vlastitih teoloških tvrdnji. Time Metz poziva na oživljavanje »anamnetičkoga duha « Izraela koji je osjetljiv na krize vjere i katastrofe kroz povijest. Kad se potom ta anamnetička racionalnost poveže s biblijskom apokaliptičkom sviješću, onda nastupa temporalizacija ahistorijskih metafizičkih postavki teologije tako da više ne može zanemariti trpljenje drugoga. ${ }^{19} \mathrm{U}$ skladu s tim Crkva je pozvana biti institucionalizirano »akumulirano sjećanje «, a navještaj evanđelja sinteza pologa vjere i iskustva povijesti trpljenja izraženoga kroz spomen na tuđu patnju. ${ }^{20}$

Nova politička teologija tako smjera na kritičku analizu i korektiv društveno-političke prakse. Sam Metz identificirao je »antropologiju vladavine « u srži politike kao povijesni i još uvijek prisutan uzrok globalnih političkih i ekonomskih nepravdi, koje potom dodatno pogoršava postmodernističko povlačenje od odgovornosti za svijet. Metzov prvotni odgovor na taj problem jest »antropološka revolucija $\ll$, sinteza moralnosti i politike na jedan netotalitaran način. ${ }^{21}$ Taj je koncept potom razvio $\mathrm{u} \gg$ svjetski program kršćanstva $\mathrm{u}$ dobu globalizacije $\mathrm{i}$ njezinoga konstitutivnog pluralizma religija i kultura $\ll^{22} \mathrm{i} \gg$ mistiku otvorenih očiju «. Riječ je o mističko-političkoj praksi vjere koja razotkriva sve samoobmane kojima se moderno društvo imunizira na tuđu patnju i moralnom zahtjevu za univerzalnom solidarnošću. ${ }^{23}$

Metz dakle zahtijeva da u središtu crkvene i teološke pozornosti bude povijest prožeta boli i nepravdom koja traži »formuliranje vjere u kategorijama otpora spremnog za patnju i promjenu $\ll^{24}$. No takvo shvaćanje kršćanske vjere počiva na predodžbi odsutna i dalekoga Boga, kojega vjernik zaziva u svojoj tjeskobi iščekujući apokaliptičko-eshatološki rasplet takva stanja. Time se isključuje utjeha zbog Božje bliskosti i prisutnosti, zbog Boga koji je u Isusu Kristu postao čovjekom ne bi li objavio evanđelje, tu »radosnu « vijest o čovjekovu spasenju. Takvo što je pod

\footnotetext{
${ }^{19}$ Usp. J. B. METZ, Memoria passionis: provokativni spomen u pluralističkom društvu, 68-83., 99-101.

${ }^{20}$ Usp. J. B. METZ, Politička teologija: 1967. - 1997., 282-287.

${ }^{21}$ Usp. J. B. METZ, The Emergent Church: The Future of Christianity in a Postbourgeois World, New York, 1981., 34-37., 42-47.

${ }^{22}$ J. B. METZ, Memoria passionis: provokativni spomen u pluralističkom društvu, 218.

${ }^{23}$ Usp. isto, 38-41., 138-141., 218-233., 317-320.

${ }^{24}$ J. B. METZ, Politička teologija: 1967. - 1997., 171.
} 
sumnjom kao neki oblik izbjegavanja teodicejskoga pitanja o razlogu patnje koje motivira na otpor pomirenju s postojećim stanjem svijeta. ${ }^{25}$

Istina, Metz isprva pomoću »eshatološkoga pridržaja «, a onda i asocirajući memoria passionis s eshatološkom nadom, odbacuje i nastoji onemogućiti političku ideologizaciju kraljevstva Božjega u neku ovozemaljsku hilijalističku utopiju. No papa Benedikt XVI., koji još od osamdesetih godina 20. stoljeća kritizira političke teologije - ponajprije teologiju oslobođenja, a onda i novu političku teologiju, upozorava kako eshatološko usmjerenje Metzova teološkoga projekta uz lajtmotiv osjetljivosti na patnju zapravo uzrokuje antihistorijski stav. Koncentrirajući se samo na konstantu trpljenja u povijesti, nova politička teologija svesrdno prihvaća apokaliptički svjetonazor i potencira mesijanski žar koji se lako može pretvoriti u poništenje političkoga. Papa Benedikt prigovara Metzu što reducira kršćansku vjeru na dramatični protest, na vrisak, zaboravljajući da je vjera vjera u uskrsnuće Kristovo, a to znači da ona nije samo spomen čovjekovih oskvrnuća, nego i spomen čovjekove veličine $\mathrm{u}$ Kristu. ${ }^{26}$

\section{2. $\gg$ Teologija naroda $\ll$ pape Franje}

Bitni naglasci pontifikata pape Franje poput evangelizacije i neizostavnosti milosrđa pri obavljanju misijskoga poslanja $\mathrm{Crkve}^{27}$ ukorijenjeni su u nauku Drugoga vatikanskoga sabora. ${ }^{28}$ No Papin je svjetonazor također oblikovan povijesnim iskustvima i društvenim okolnostima Južne Amerike: suživotom domorodaca, europskih doseljenika i afričkih robova te napetostima zbog nejednakosti, jazom između bogatih i siromašnih, posljedicama vojnih diktatura i autoritarnih režima te korupcijom i organiziranim kriminalom. Osim toga biografskoga konteksta, teološki nazori Svetoga Oca ukorijenjeni su i u teología del pueblo, odnosno $\gg$ teologiji naro$\mathrm{da} \ll$, koja predstavlja argentinski odgovor na teologiju oslobođenja. Ta »teologija naroda « bavi se nastankom i rastom $\gg$ naroda $<\mathrm{u}$ smislu Božje $\gg$ predrage svojine $\ll$ (usp. Izl 19, 5; Pnz 14, 2 - 26, 18) na putu spasenja. Riječ je o utjelovljenju novozavjetnoga $\gg$ naroda Božjeg $\ll^{29} \mathrm{u}$ svakom krštenom pojedincu, u samoj zajednici i

\footnotetext{
${ }^{25}$ Usp. I. RAGUŽ, Johann Baptist METZ, Memoria Passionis. Ein provozierendes Gedächtnis in pluralistischer Gesellschaft, Herder, Freiburg - Basel - Wien, 2006., 274 str., u: Bogoslovska smotra 76(2006.) 1, 229-231., ovdje 231.

${ }^{26}$ Usp. I. RAGUŽ, Papa Benedikt XVI. O Crkvi, državi i politici, u: ISTI, Teološki fragmenti III., Panni, Đakovo, 2017., 338-341.

${ }^{27}$ Usp. LG, br. 2-9, 16, 43; usp. GS, br. 3, 17; usp. AG, br. 3-8.

${ }^{28}$ Usp. A. MATELJAN, Božje milosrđe i naše spasenje, u: Bogoslovska smotra 86(2016.)3, 597-623., ovdje 611-614.

${ }^{29}$ Usp. LG, br. 9-17.
} 
kulturi kao specifičnom obliku zajedničkoga života. Taj povijesni hod »naroda « jest proces sazrijevanja subjektnosti zajednice koji se ne može ostvariti paternalistički, namećući »odozgo « izvršnim odlukama vjerske, kulturne i društvene vrijednosti. To se ne odnosi samo na sekularnu vlast, nego i na crkvenu hijerarhiju, koja vjerodostojno obavlja svoju službu onda kad uvažava da »narod « jest Crkva. Navještaj evanđelja inkulturacijom organski stvara zajednicu vjernika koja je subjekt vlastite društvene zbilje i povijesnoga hoda prema Bogu. ${ }^{30}$

Naravno, $\gg$ teologija naroda « poziva i na konkretne napore oko socijalne pravednosti, ali se ne oslanja na marksističku analizu političkih i ekonomskih uvjeta poput teologije oslobođenja. Zato se papa Franjo ne zadržava samo na temama pravedne raspodjele resursa, održivoga gospodarskoga razvoja i političke emancipacije i poštovanja ljudskih prava, smjerajući uvijek na to zašto i kako život društva treba biti oblik zajedničkoga življenja vjere, koji daje plodove mira i pravednosti, ${ }^{31}$ što je preduvjet za spasenje duša. Praksa vjere ovdje je dimenzija identiteta $\gg$ naroda $\ll$ izrasla iz povijesnih i kulturnih veza koje se ne može u cijelosti objasniti marksističkim reduciranjem društvene zbilje na dinamiku klasne borbe zbog nepravednih materijalno-ekonomskih odnosa. ${ }^{32}$

Crpeći također iz svojih pastoralnih iskustava i »teologije naroda «, papa Franjo u apostolskoj pobudnici Evangelii gaudium - Radost Evandelja sažima svoj pristup u nekoliko ključnih načela: a) primat vremena nad prostorom; b) primat jedinstva nad sukobom; c) primat zbilje nad idejom; d) superiornost cjeline nad njezinim sastavnicama. $^{33}$

Michael Kirwan smatra načelo primata vremena ključnim za Papin pastoralno-teološki pristup. Papi Franji »prostor « služi kao metafora za sukobe oko ograničenih materijalnih resursa i teritorija, za racionalnost demarkiranja vlastitoga od tuđega i promicanja vlastitih interesa ispred općega dobra. No »vrijeme « dopušta različitim skupinama koje dijele isti ograničeni fizički prostor razviti zajedničku povijest i kulturu, kao i svijest o zalogu u istoj budućnosti. Zato papa Franjo kritizira kratkoročno, »prostorno « razmišljanje i djelovanje u javnom životu i politici danas, koje opravdava individualizam i sebičnost na štetu ranjivih i ugroženih, i na lokalnoj razini i globalno. Taj izostanak solidarnosti, a time i pravednosti, tema je koju

\footnotetext{
${ }^{30}$ Usp. M. KIRWAN, Time, the Mercy of the Messiah. Pope Francis and Johann Baptist Metz, u: J. K. DOWNEY, S. OSTOVICH, J. M. VENTO (ur.), Facing the World: Political Theology and Mercy, New York, 2018., 57-62.

${ }^{31}$ Usp. EG, br. 217-221.

${ }^{32}$ Usp. G. DIETLEIN, Teología del pueblo. Schlüsselstein zum Denken von Papst Franziskus, u: Münchener Theologische Zeitschrift 67(2016.)1, 54-66., ovdje 59-62.

${ }^{33}$ Usp. EG, br. 222-237.
} 
papa Franjo uvijek iznova dotiče iz različitih perspektiva u svojim enciklikama i pobudnicama.

U apostolskoj pobudnici Amoris laetitia - Radost ljubavi papa Franjo daje do znanja kako načelo prednosti vremena nad prostorom primijeniti na upravljanje Crkvom. ${ }^{34}$ Svaka odluka nametnuta $\gg$ odozgo « isključuje mnogostrukost perspektiva i sva alternativna rješenja, koja bi se inače s vremenom organski razvila unutar lokalne zajednice. Stoga su ostala tri načela njegova teološko-pastoralnoga pristupa, zapravo, daljnja razrada toga što zapravo podrazumijeva voditi Crkvu dajući prednost »vremenu «, tj. samom povijesnom razvoju vjerničke zajednice, ne dopuštajući trenutačnim, $\gg$ prostornim $\ll$ brigama da zamagle dugoročnu perspektivu. Tako načelo promicanja jedinstva nad sukobom nalaže prepoznati različite životne situacije mjesnih Crkava i raznolikost oblika življenja vjere u globalnoj Crkvi koja treba svjesno raditi na unutarcrkvenom dijalogu. I upravo ta kulturna policentričnost Crkve isključuje nametanje nekoga apstraktnoga ideala što bi Crkva trebala biti i kako bi trebalo živjeti vjeru. Cilj je integracija različitih oblika vjerskoga života u općoj Crkvi, a opet poštujući subjektnost lokalnih vjerskih zajednica pri suočavanju s krizama i izazovima. ${ }^{35}$

Papa Franjo ta načela ne primjenjuje samo na unutarcrkvena pitanja, nego i na situaciju Crkve u svijetu, koju vidi kao univerzalni instrument Božjega milosrđa ${ }^{36}$, kao što se može vidjeti u papinskoj buli Misericordiae vultus kojom je najavljen Izvanredni jubilej milosrđa. ${ }^{37}$ Ovdje je na djelu nauk Drugoga vatikanskoga sabora koji traži od Crkve neka se odrekne kroz povijest stečenih privilegija ne bi li baš poput siromaha kojima je poslana, pouzdajući se samo u Božju pomoć, živjela opredijeljenost za ugrožene. ${ }^{38}$

Enciklike Laudato si' i Fratelli tutti služe kao svojevrsni manifest upravo te nakane, gdje papa Franjo poručuje kako se evangelizacijsko poslanje Crkve ne svodi na deklarativni navještaj evanđelja, nego podrazumijeva i preobrazbu društva kroz spasonosni susret po uzoru na parabolu o milosrdnom Samarijancu. ${ }^{39}$ Odgovor na svjetske krize i probleme jesu karitativnost, velikodušnost i solidarnost, po kojima

\footnotetext{
${ }^{34}$ Usp. AL, br. 3.

${ }^{35}$ Usp. M. KIRWAN, Time, the Mercy of the Messiah. Pope Francis and Johann Baptist Metz, 57-62.

${ }^{36}$ Usp. MV, br. 3-4, 12, 24-25.

${ }^{37}$ Usp. A. TAMARUT, Crkva u nauku pape Franje, u: Bogoslovska smotra 87(2017.)1, 59-78., ovdje 67-69., 74-76.

${ }^{38}$ Usp. S. DIANICH, Učiteljstvo pape Franje - nove perspektive, u: Riječki teološki časopis 24(2016.)2, 329-350., ovdje 345-347.

${ }^{39}$ Usp. FT, br. 56, 63-82.
} 
se očituje čovjekova sličnost s Bogom..$^{40}$ Božje milosrđe potvrđuje transcendentalno izvorište čovjekova neotuđiva dostojanstva i kontekstualizira težnju $\mathrm{k}$ pravednosti i miru za sve, ne samo u smislu oslobođenja od otuđujućih spona u sadašnjem trenutku nego i spasenja za vječnost. ${ }^{41}$

Zato papa Franjo, u ovom povijesnom trenutku kada čovječanstvo postaje uistinu globalna zajednica, potiče na međunarodnu suradnju oko hitnih izazova modernog doba kao što su klimatske promjene i održivi razvoj ${ }^{42}$ te upozorava na izostanak solidarnosti prema marginaliziranima, a napose usred tekuće migrantske krize. ${ }^{43}$ Papa Franjo zalaže se za samoorganizaciju i umrežavanje lokalnih zajednica prema načelu supsidijarnosti. Cilj mu je naglasiti važnost očuvanja povijesno-kulturnoga nasljeđa, ali i gajiti kulturu susreta i osjetljivosti za drugoga. ${ }^{44} \mathrm{Uz}$ to se kritički obazire na korozivan utjecaj privatnih ekonomskih interesa i nesavjesne primjene tehnologije po društvo. ${ }^{45}$ Dakle Papine društveno-političke osvrte uvijek treba razumijevati u svjetlu poziva na rast u svetosti, ne samo u osobnom življenju vjere nego i kroz suživot u zajednici, susretanjem i zalaganjem za bližnjega, čime se vjerodostojno svjedoči evanđelje. ${ }^{46}$

\section{Komplementarne teme $i$ »postidealistički $\ll$ pristup}

\subsection{Patnja i milosrge}

Središnje teme i nove političke teologije i pastoralno-teološkoga nazora pape Franje ukorijenjene su u povijesnim okolnostima njihova nastanka. Metzova osobna iskustva u Drugom svjetskom ratu i kolektivna trauma holokausta, a potom hladni rat i raspad europskih kolonijalnih posjeda razlog su zašto nova politička teologija govori o čovjekovu odnosu prema Bogu s obzirom na stradanja u povijesti. Polazeći od teodicejskoga pitanja o razlogu patnje, Metz odbacuje dominantan soteriološki ton prisutan u teologiji »prije Auschwitza «. Pretpostavka kako je Božji spasenjski naum već dovršen opravdava pasivnost u življenju vjere i ispričava od iskanja pravde za trpeće. No njihova bol odjekuje u Kristovoj memoria passionis, koja je ujedno i »anticipacijsko sjećanje « na eshatološko Božje obećanje pravde za sve žrtve u povijesti - uskrsnuće mrtvih. Ne bi li naglasio breme i sablazan te povi-

\footnotetext{
${ }^{40}$ Usp. isto, br. 10-28, 37-46, 103-105, 114-127, 139-141, 146-148, 177-185.

${ }^{41}$ Usp. isto, br. 84-86, 271-276.

${ }^{42}$ Usp. LS, br. 48-52, 138-158, 164-175, 189-198.

${ }^{43}$ Usp. FT, br. 37-43, 121-141.

${ }^{44}$ Usp. LS, br. 176-181, 199-200, 231-232; usp. FT, br. 142-150, 177-183, 226, 246-249.

${ }^{45}$ Usp. LS, br. 53-59, 102-136, 203-232; usp. FT, br. 42-53, 155-175.

${ }^{46}$ Usp. GE, br. 2-9, 110-111, 140-146.
} 
jesne svijesti o opsegu trpljenja, Metz Božji spasenjski zahvat tumači apokaliptički, kao $\gg$ prekid $\ll$ ove povijesti. $^{47}$

No za papu Franju, koji dolazi iz Južne Amerike, gdje europski kolonizatori, domorodci i kasniji doseljenici unatoč teretu kolonijalne povijesti žive jedni uz druge te miješaju svoja kulturna nasljeđa i krv do neraspoznatljivosti, takva perspektiva nije samorazumljiva. Iako i Latinska Amerika ima svoje zločince i žrtve, nipošto nije »stari « kontinent poput Europe. Nekadašnjim europskim kolonijama, iako su još uvijek siromašne i ekonomski iskorištavane, tek predstoji postati gospodarima vlastite sudbine. Zato se za Svetoga Oca transformacijski učinak eshatona na povijest ne ostvaruje njezinim » prekidom «, već kao kontinuirani povijesni proces rasta subjektnosti $\gg$ naroda $\ll$ koji putuje ususret Kristu. ${ }^{48}$

Unatoč različitom društveno-povijesnom kontekstu, pastoralno-teološki pristup pape Franje izrastao iz »teologije naroda « i nova politička teologija Johanna Baptista Metza jednako su plod Drugoga vatikanskoga sabora. Obje su teologije osjetljive na povijesnu situaciju Crkve kojoj se obraćaju, a koja »sve više postaje - zapravo 'jest' - Crkvom 'Trećeg svijeta' s konstitutivno zapadno-europskom poviješću svog početka $\ll^{49}$. Metz je od početka, još od Biskupske konferencije u Medelinu 1968. godine, sa zanimanjem pratio razvoj teologije oslobođenja. Nakon što je sam posjetio Latinsku Ameriku osamdesetih godina 20. stoljeća, potresna iskustva nepravde i siromaštva kojima je svjedočio potaknula su ga da artikulira praksu vjere kao $\gg$ mistiku otvorenih očiju «. Time je novu političku teologiju izmjestio iz izvornoga eurocentričnoga okruženja u globalan kontekst ne bi li mogao izraziti zahtjev za uistinu univerzalnom solidarnošću. ${ }^{50}$

Nije teško zamisliti zašto bi nova politička teologija privukla pozornost latinoameričkih teologa oslobođenja. Čitajući Metza, pronašli bismo iz pera prominentnoga akademskoga teologa potvrdu vlastitih stremljenja - zahtjev za postidealističkom paradigmom bavljenja teologijom. ${ }^{51}$ Riječ je o novom odnosu teorije i prakse, odnosno teološke refleksije i življenja vjere, koji je sad određen »primatom prakse «. Metz je htio učiniti teologiju osjetljivom na iskustva patnje u povijesti, a onda zbog postkolonijalne eksploatacije zemalja Trećega svijeta i perceptivnom na težnju za oslobođenjem zbog opresivnih i otuđujućih društveno-političkih uvjeta. Teologija

\footnotetext{
${ }^{47}$ Usp. J. B. METZ, Politička teologija: 1967. - 1997., 187-190.

${ }^{48}$ Usp. M. KIRWAN, Time, the Mercy of the Messiah. Pope Francis and Johann Baptist Metz, 67-69.

${ }^{49}$ J. B. METZ, Politička teologija: 1967. - 1997., 171.

${ }^{50}$ Usp. J. M. ASHLEY, Interruptions: mysticism, politics, and theology in the work of Johann Baptist Metz, Notre Dame, 1998., 199-204.

${ }^{51}$ Usp. isto, 1-8.
} 
bi trebala moći kritički pristupiti podrazumijevanim i nepreispitanim pretpostavkama o svijetu koje omogućavaju proliferaciju nepravednoga društvenoga statusa quo. Isto tako takav teološki pristup korigirao bi i razumijevanje uloge vjere $\mathrm{u}$ društvu i povijesti, kao i tendenciju prisutnu u teologiji: zatvoriti se u ahistorijske, objektivističke reprodukcije prijašnjih izričaja vjere, koji su izgubili svoju izvornu egzistencijalnu težinu i nisu više na taj način inteligibilni u trenutačnoj povijesnoj situaciji. $^{52}$

Takav korektiv za Papu predstavlja promatrati povijest spasenja te odnos vjere i svijeta kroz leću milosrđa. Papa Franjo razumije milosrđe kao Božje raspoloženje prema čovjeku u njegovoj nemoći. Milosrđe je razlog zašto transcendentni Bog utjelovljenjem premošćuje jaz između sebe i čovjeka i zašto je Božji spasenjski zahvat u povijest obilježen $\gg$ solidarnim suosjećanjem «. Čovjekova pala narav ni sva posljedična patnja u povijesti stoga ne opravdava beznađe, kao ni rezigniranost na potrebu bližnjega. U apostolskom pismu u povodu zatvaranja Izvanrednoga jubileja milosrda, naslovljenom Misericordia et misera - Milosrde i bijednica ${ }^{53}$, susret Isusa i preljubnice iz Ivanova evanđelja prikazan je kao milosno iskustvo koje potiče na obraćenje. ${ }^{54}$ Time papa Franjo ističe što je u Metzovoj novoj političkoj teologiji već bilo implicitno sadržano. Milosrđe je odgovor na čovjekovo teodicejsko pitanje koje ne bi imalo smisla ni postavljati bez vjere i nade u odgovor koji će očitovati Božju ljubav. ${ }^{55}$

\subsection{TEMELJNI HERMENEUTIČKI PROBLEM}

Utjecaj teologije oslobođenja na novu političku teologiju može se vidjeti iz tema kojih se Metz dotiče u osamdesetim i devedesetim godinama 20. stoljeća, kao i iz pozitivnih opaski o oblicima prakse vjere u Latinskoj Americi. Metz je teologiju oslobođenja, koja razumije vjeru komplementarno oslobođenju od opresije, nepravde i otuđenja, smatrao ponajviše dosljednim ostvarenjem postidealističke paradigme teologije. ${ }^{56}$ Stoga u istom svjetlu treba promatrati i odjeke Metzove nove političke teologije u pastoralno-teološkom pristupu pape Franje.

\footnotetext{
${ }^{52}$ Usp. J. B. METZ, Faith in History and Society: Toward a Practical Fundamental Theology, 29-34., 60-68., 81-84.

${ }^{53}$ FRANJO, Misericordia et misera - Milosrde i bijednica. Apostolsko pismo na zaključenju izvanrednoga jubileja milosrda, Zagreb, 2017. (= MM).

${ }^{54}$ Usp. MM, br. 1.

${ }^{55}$ Usp. J. M. ASHLEY, Mercy, Theology and Sprituality, u: J. K. DOWNEY, S. OSTOVICH, J. M. VENTO (ur.), Facing the World: Political Theology and Mercy, 76-85.

${ }^{56}$ Usp. J. B. METZ, The Emergent Church: The Future of Christianity in a Postbourgeois World, 56-65.
} 
Ponajprije, središnja načela Papina teološkoga nazora iz pobudnice Evangelii gaudi$u m^{57}$ ispunjenje su Metzova poziva na temporalizaciju teologije. Takav pristup dopušta promišljati nad društveno-povijesnom situacijom u kojoj se nalazi zajednica vjernika, a onda i pitati kako bi Crkva kao institucionalizirani oblik življenja vjere trebala djelovati u svijetu. Papa Franjo ostaje na liniji Metzova poimanja mističkopolitičke zadaće Crkve u društvu i povijesti čiji je cilj učiniti čovjeka subjektom pred Bogom. ${ }^{58}$ No budući da papinska služba podrazumijeva i stalan rizik politizacije svake izjave, kao i teologizacije trenutačnoga političkoga pravorijeka, papa Franjo pristupa temama kojih se dotiče u svojim enciklikama i ostalim dokumentima uvijek jasno dajući do znanja kako je riječ o »teološkoj hermeneutici političke etike $\ll .{ }^{59}$

Tako je u enciklici Laudato si' kritika suvremene konzumerističke kulture uprizorena kao prepreka po povijesni proces sazrijevanja $\gg$ naroda $\ll$, odnosno rasta zajednice u svetosti. ${ }^{60}$ Isto tako enciklika Fratelli tutti upozorava na nekompatibilnost (post)modernoga moralnoga relativizma s kulturom autentičnoga susreta i dužnošću održavanja kolektivnoga sjećanja radi međusobnoga praštanja i pomirenja. ${ }^{61}$ Time se, naravno, ne isključuje $\mathrm{i} \gg$ politička « poruka kako individualizam i ekscesivni konzumerizam ide na ruku ekonomskim i političkim interesima elite, a na štetu i osiromašenje svih ostalih. Dakle, za Papu, čovjek kao subjekt društva i povijesti, a istodobno $\mathrm{i} \gg$ subjekt pred Bogom «, ne može ignorirati odgovornost za svijet ni patnju bližnjega s kojim dijeli isti povijesni trenutak i usud. ${ }^{62}$

Na sličan način apostolska pobudnica Gaudete et exsultate govori o pozivu na rast $\mathrm{u}$ svetosti, u svakodnevici i unutar vlastite zajednice, što je vjerodostojno svjedočanstvo vjere. Za papu Franju ponajprije su djela milosrđa i blaženstva ${ }^{63}$, koje shvaća kao nastojanje oko socijalne pravednosti i kao jednu dublju preobrazbu svijeta sličnu Metzovoj »antropološkoj revoluciji «, najizvrsniji način prakse vjere i suobličavanja Kristu. ${ }^{64}$

\footnotetext{
${ }^{57}$ Usp. EG, br. 222-237.

${ }^{58}$ Usp. J. B. METZ, Theology of the World, 115-124.; ISTI, Faith in History and Society: Toward a Practical Fundamental Theology, 81-84.

${ }^{59}$ Usp. J. B. METZ, Politička teologija: 1967. - 1997., 37-38., 61-67.

${ }^{60}$ Usp. LS, br. 115-128, 142-162.

${ }^{61}$ Usp. FT, br. 236-254.

${ }^{62}$ Usp. M. KIRWAN, Time, the Mercy of the Messiah. Pope Francis and Johann Baptist Metz, 63-65.

${ }^{63}$ Usp. Mt 5, 3-12.

${ }^{64}$ Usp. GE, br. 65-94.
} 
Papa Franjo govoreći o pozivu na svetost mimo elitističkoga intelektualističkoga pristupa pologu vjere ${ }^{65} \mathrm{i}$ ideoloških okršaja oko aktualnih sporova u društvu ${ }^{66} \mathrm{za}-$ pravo govori o primatu prakse vjere. Evanđelje je poziv na djelovanje i to na rubu bilo društva bilo vlastite zone komfora, vazda na putu prema susretu s Bogom koji je $\gg$ vječno novo $\ll .{ }^{67}$ Papino poimanje življenja vjere odražava duh Drugoga vatikanskoga sabora, ali i zrcali novu političku teologiju koja kritizira pasivnost i samozadovoljstvo europske $\gg$ buržujske religije $\ll{ }^{68}$ te poziva na praktično nasljedovanje Krista u svjetlu eshatološkoga usmjerenja povijesti koje otkriva svijet kao »pozornicu « za dramu čovjekova pada i otkupljenja. ${ }^{69}$

Na tom tragu, apostolska pobudnica Querida Amazonia promišlja o misijskom poslanju Crkve u Amazoniji uvažavajući urođeničke kulture i njihovo pravo na samoodređenje, kao i nastojanje oko što veće socijalne pravednosti. ${ }^{70} \mathrm{Uz}$ osjetljivost na bijedu i siromaštvo, to znači i odgovoriti na izazov očuvanja okoliša. ${ }^{71}$ Papa Franjo na primjeru Amazonije predlaže kako pristupiti čovjeku u njegovoj društveno-povijesnoj situaciji i navijestiti mu evanđelje bez da ga se otuđi od njegovih korijena i time mu se zaniječe preuzimanje odgovornosti za vlastitu zajednicu i svijet. Drugim riječima, kako postati $\gg$ subjektom pred Bogom $\ll .^{72}$

Pitanje subjektnosti u društvu i povijesti, a posebno »pred Bogom «, također je i tema apostolske pobudnice Christus vivit, koja se obraća mladima i ističe važnost ukorijenjenosti u obitelji i zajednici, u vlastitoj kulturi i vjerskoj tradiciji. Za Papu Isusov rani život u Nazaretu predstavlja ogledni primjer »zajednice na putu « (grč. synodia) kakva bi trebala biti i Crkva. Taj poziv na veću sinodalnost i supsidijarnost u Crkvi nije samo pitanje ustroja crkvene institucije, već raspoloženje dijaloga i razmjene iskustava, pa i konstruktivne kritike, kao i preuzimanja odgovornosti za život Crkve i njezino poslanje. ${ }^{73}$ Što potpunije ucjepljenje u obitelj i lokalnu zajednicu, što uključuje i Crkvu, jest jamstvo očuvanja njihove ljudskosti nasuprot otuđujućim trendovima u globaliziranom društvu, koje promiče egoizam konzume-

\footnotetext{
${ }^{65}$ Usp. isto, br. 35-46.

${ }^{66}$ Usp. isto, br. $48-59$.

${ }^{67}$ Usp. isto, br. 96-98, 104-109, 135-139.

${ }^{68}$ Usp. J. B. METZ, The Emergent Church: The Future of Christianity in a Postbourgeois World, 67-75.

${ }^{69}$ Usp. J. B. METZ, Theology of the World, 16-25., 51-60., 81-97.

${ }^{70}$ Usp. QA, br. 14-17, 66-69, 104-105.

${ }^{71}$ Usp. isto, br. 41, 61-65, 75-76.

${ }^{72}$ Usp. J. B. METZ, Faith in History and Society: Toward a Practical Fundamental Theology, 58-59., 70-78., 208-214.

${ }^{73}$ Usp. CV, br. 23-29, 39-42, 203-208.
} 
rizma, individualizma i duhovnosti bez Boga. ${ }^{74}$ Odražavajući Metzova upozorenja o $\gg$ kulturnoj amneziji $\ll$ i poticaje na obnovu $\gg$ anamnetičkoga uma $\ll$, papa Franjo podsjeća na vrijednost kolektivnoga sjećanja koje stariji prenose mladima i koje bi mladi trebali prenijeti vlastitoj djeci. ${ }^{75}$ Isto tako Papin poticaj na sinodalnost zrcali Metzov zahtjev za unutarcrkvenom kritičkom javnosti radi očuvanja autentičnoga života vjere u Crkvi. ${ }^{76}$

\section{Zaključak}

Nedvojbeno, Johann Baptist Metz i papa Franjo dijele mnoge zajedničke teme, a može se čak prepoznati i određena srodnost njihovih ideja. Ipak, svrha ovoga članka nije bila samo sadržajno povući paralele i istaknuti dodirne točke. Kada je to i učinjeno, uvijek je bilo radi naglašavanja one stvarne poveznice između nove političke teologije i pastoralno-teološkoga nazora Svetoga Oca. Riječ je, naravno, o postidealističkoj teološkoj paradigmi koja se nalazi u srži Metzova projekta artikulacije teologije osjetljive na društveno-političku praksu, teologije koja je primarno antropocentrična, tj. koja pita kako postati »subjekt pred Bogom « i promišlja nad življenom praksom vjere u povijesti.

Pastoralno-teološka načela pape Franje iz apostolske pobudnice Evangelii gaudium (usp. EG, br. 222-237), napose o primatu vremena nad prostorom, čine daljnju razradu i praktičnu primjenu tih ključnih postavki Metzova teološkoga projekta, izvorno u povijesnom i kulturnom kontekstu Latinske Amerike, a sada prenesenoga na cijelu Katoličku Crkvu. Sam Metz je još u sedamdesetima, zbog izostanka potpore crkvene hijerarhije za projekt interdisciplinarnoga teološko-sociološkoga instituta u Bielefeldu, prepoznao da ostvarenje njegovih ideja nije vjerojatno $u$ »buržujskoj « Europi. ${ }^{77}$ Odgovor na njegov posljedični poziv na »antropološku revoluciju «, ne samo na veću osjetljivost na patnju nego i na otpor nepravednim političkim i ekonomskim praksama pomoću kojih gospodarski razvijene zemlje drže ostatak svijeta u svojevrsnom dužničkom ropstvu, došao je upravo iz Trećega svijeta.

Na neki način, budućnost nove političke teologije i nije se mogla razviti drukčije. Volja za promjenom može doći samo iz sveprisutnoga i generacijskoga iskustva nepravde i trpljenja kakvo izostaje na Zapadu. Ili se javno ne priznaje. Metz je pak, počevši sa židovskim holokaustom, omogućio drugima, poput argentinske »teologije

\footnotetext{
${ }^{74}$ Usp. isto, br. 179-186, 217, 259-267.

${ }^{75}$ Usp. isto, br. 192-197, 262-264.

${ }^{76}$ Usp. J. B. METZ, Politička teologija: 1967. - 1997., 29-34.

${ }^{77}$ Usp. T. R. PETERS, Johann Baptist Metz. Theologie des vermißten Gottes, Mainz, 1998., 83-93.
} 
naroda $\ll$, da svoja povijesna iskustva inteligibilno komuniciraju u okviru još uvijek pretežno eurocentrične idealističko-transcendentalističke akademske teologije. Nova politička teologija time je postala kritički aparat za analizu i situacije vjere u svijetu i problema unutar same Crkve koji sprječavaju autentično življenje vjere u duhu Drugoga vatikanskoga sabora koji je obećao uvesti $\gg$ načine izlaganja pologa vjere više prilagođene učiteljstvu koje je po svojoj prirodi ponajprije pastoralno $\ll{ }^{78}$.

I stoga se kod pape Franje može prepoznati »svjetski program kršćanstva u dobu globalizacije i njezinoga konstitutivnog pluralizma religija i kultura $\ll^{79}$ uvelike sličan Metzovim zaključcima i poticajima. Papa Franjo tako poziva na inkulturaciju evanđelja, što bi onda olakšalo prepoznavanje i uvažavanje drugoga u ovoj kulturno policentričnoj Crkvi, u zajedničkom hodu prema eshatonu. Iz istoga razloga ne oklijeva, u smislu $\gg$ teološke hermeneutike političke etike ${ }^{80}$, govoriti o gorućim globalnim problemima i izazovima koji ugrožavaju i neposrednu sutrašnjicu i eshatološku budućnost čovječanstva. Za taj »postidealistički « pastoralno-teološki pristup ključna je upravo povijesna svijest, odnosno »anamnetički duh « osjetljiv na krize i nepravdu, ali i osjećaj za Božje milosrđe ne bi li se na patnju bližnjega odgovorilo solidarnošću, jer se spasenje ne može poimati zasebno od težnje za slobodom, mirom i pravdom.

${ }^{78}$ IVAN XXIII., Gaudet Mater Ecclesia. Allocutio Ioannis PP. XXIII in solemni SS. Concilli inauguratione (11. X. 1962.), br. 6. Dostupno na: https://www.vatican.va/content/john-xxiii/la/speeches/1962/documents/hf_j-xxiii_spe_19621011_opening-council.html (3.11.2021.).

${ }^{79}$ J. B. METZ, Memoria passionis: provokativni spomen u pluralističkom društvu, 218.

${ }^{80}$ J. B. METZ, Politička teologija: 1967. - 1997., 38. 


\title{
HERMENEUTIC CONTINUITY BETWEEN J. B. METZ AND POPE FRANCIS
}

\author{
Ivica RAGUŽ* - Mirko VLK**
}

Summary: The article examines parallel themes between the new political theology of Johann Baptist Metz and the pastoral-theological approach of Pope Francis seeking a deeper connection beyond the common heritage of the Second Vatican Council. By comparing the post-idealist theological paradigm of the new political theology, as well as its task of being the »theological hermeneutics of political ethics «, and the Pope's pastoral principles from the apostolic exhortation Evangelii gaudium, rooted in the Argentine > theology of the people«, the article concludes that Metz and the Holy Father share the emphasis on historical consciousness in theological reflection, more precisely, that the expression of the deposit offaith and the practice offaith are conditioned by socio-historical circumstances which is why salvation cannot be considered separately from the pursuit of freedom, peace, and justice. From this, Metz's theodically expressed sensitivity to suffering and the Pope's emphasis on God's mercy also complement each other.

Keywords: new political theology, Johann Baptist Metz, Pope Francis, mercy, theological hermeneutics of political ethics, suffering.

\footnotetext{
* Full Prof. Ivica Raguž, Ph.D., Catholic Faculty of Theology in Đakovo, J. J. Strossmayer University of Osijek, Petra Preradovića 17, P. O. box 54, 31400 Đakovo, Croatia, ivica.raguz@os.t-com.hr

** Mirko Vlk, Ph.D., Croatian Catholic Mission in Hamburg, Schmilinskystrasse 14, 20099 Hamburg, Germany, mirko.vlk.op@gmail.com
} 